\title{
Productivity in Food Crops Production: Evidence from Makueni County, Kenya
}

\author{
Mary M. Musa ${ }^{1 *}$ Perez A. Onono, $\mathrm{PhD}^{2}$ \\ 1. School of Economics, Kenyatta University, P.O Box 43844-00100 Nairobi Kenya \\ 2. School of Economics, Kenyatta University, P.O Box 43844-00100 Nairobi Kenya \\ * E-mail of the corresponding author: marianamusah@gmail.com
}

\begin{abstract}
The objective of this study was to determine the level of productivity in food crops production and establish its determinants among smallholders in Makueni County, Kenya. The study used primary data collected through one on one interviews with 100 farming households in Kaiti Constituency. Average productivity for each household in food production was computed and regressed on demographic and farm characteristics. Findings show that on average households made Kshs.21, 940 from food production in the given cropping season. For the households that rely exclusively on farming, the productivity per person was below what is required to spend to be out of poverty. Regression results indicated that; age of the household head, cultivation of own land, farming experience, access to extension services, use of high mechanized farming tools and close proximity to a market place had a positive influence on the household food crop productivity. The findings imply that, establishing rural markets within villages at a close proximity to farming households and increased engagement of extension officers from the county government to equip farmers with knowledge and skills on farming technologies can be useful strategies for enhancing food productivity and security in Makueni County.
\end{abstract}

Keywords: Smallholders, Food crops, Productivity, Determinants

DOI: $10.7176 / \mathrm{JESD} / 12-18-07$

Publication date:September $30^{\text {th }} 2021$

\section{Introduction}

The fight against hunger across the world has continued over the years yet many people still lack adequate food for an active and a healthy life. Globally, about 690 million people suffer from hunger corresponding to 8.9 percent prevalence of undernourishment (UN Hunger Report, 2020). Achieving food security requires adequate food availability, access, utilization and stability (FAO, 2006). Food availability which is the physical existence of food in sufficient quantities can be attained from household own production, purchase from the market or food aids. Food access is ensured when households have enough resources to obtain food at the market prices or sufficient resources to grow their own food (Garrett and Ruel, 1999). Individual's level of income and the price of the food are therefore critical in food accessibility and security. Food utilization relates to the ability of the human body to take food and convert it into the essential nutrients and thereby reducing the prevalence of undernourished population while, food stability require individuals and households to access food overtime which improves their resilience by minimizing external risks such as natural disasters and climate changes. (United States Agency for International Development (USAID), 1995).

Majority of Africa's population depend on agriculture for all or part of their livelihood. However, 90 percent of Africa's food supply is produced by small holders who produce very little such that majority of them are food insecure (Palitza, 2013). According to the International Food Policy Research Institute (IFPRI), in 2018, Kenya was ranked 77 out of 119 countries struggling with food insecurity, with a Global Hunger index (GHI) score of 23.2 based on the level of undernourishment, child mortality and child stunting. Smallholder production contribute up to 70 percent of the total food produced in Kenya (Onono, Wawire and Ombuki, 2013). Increased food productivity among them is therefore critical in ensuring food security in the country. Maize is a key staple food in Kenya and constitutes more than half of a smallholder household food production. Some of the other food crops grown include beans, potatoes, wheat, millet, sorghum, rice and cassava.

The trends in yield of some food crops in Kenya are shown in figure 1. 


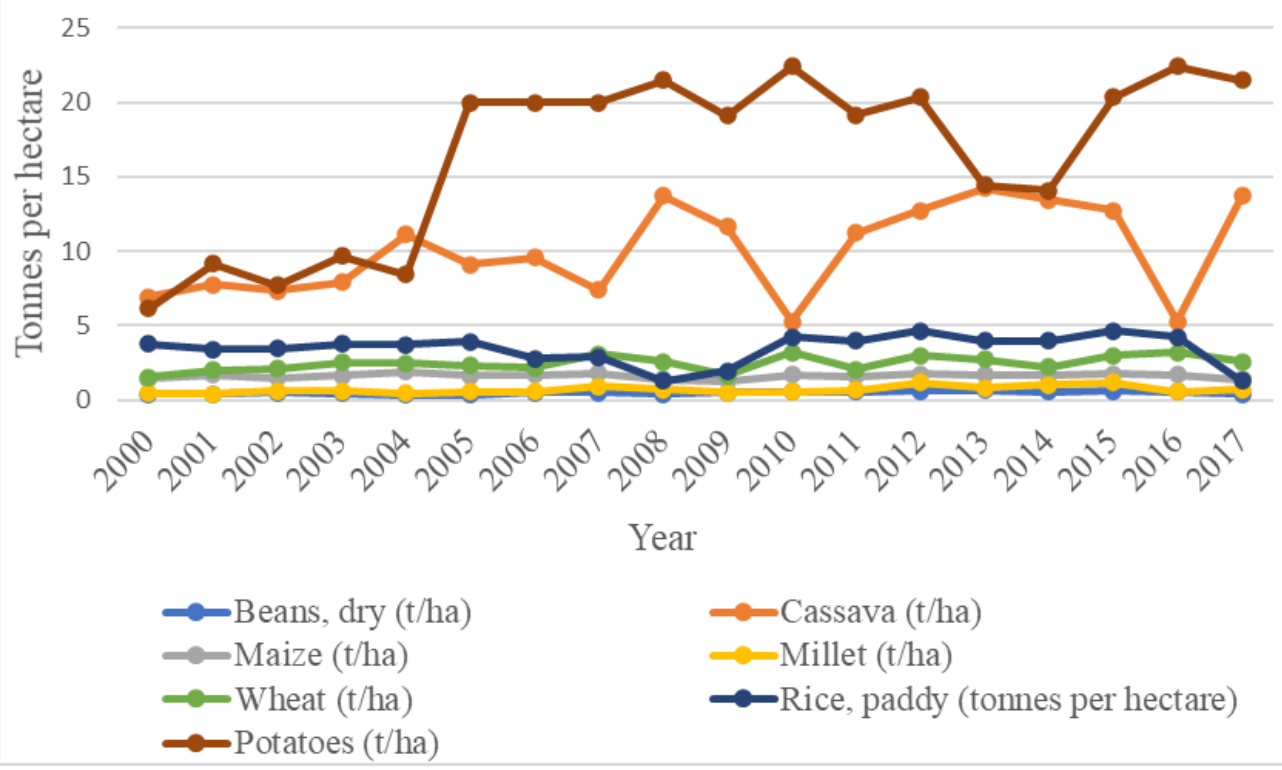

Figure 1. Average crop yields trend in Kenya for the period 2000 to 2017

Source: World Bank Data Base

Figure 1 shows that, productivity of maize, stagnated at less than two tonnes per hectare in the period 2000 to 2017. The trend is similar for other food crops including dry beans, millet and wheat. However, for other crops such as cassava and potatoes productivity flactuated, but remained relatively higher than for the other crops.

Kenya has implemented policies and strategies to increase productivity in the agricultural sector over the years. These include irrigation facilities in semi arid areas aimed at reducing over-reliance on rain-fed agriculture; policies to attract private entrepreneurs to invest in agricultural infrastructure development and promotion of modern farming techniques (Republic of Kenya, 2004). The Agricultural Sector Development Strategy (ASDS) to implement the Kenya Vision 2030 focused on two main elements. First, to ensure the agricultural sector employs farming methods and technologies to modernize agriculture and enhance productivity through investment in agricultural water management, use of improved seeds and increased use of fertilizers. Second, was to ensure that institutions providing services to farmers such as financial institutions like banks, Agricultural Finance Corporation (AFC) and other organizations like Kenya Agricultural Research Institute (KARI) and Kenya Forestry Research Institute (KFRI) are more effective and efficient (Republic of Kenya, 2010).

Makueni County is one of the counties in Kenya with low levels of food security due to poor rainfall and the existence of high temperatures which have led to poor crop harvests. The County was ranked 25 out of the 47 counties with an estimated food poverty level of 30.7 percent in the Kenya Integrated Household Budget Survey (KIHBS), conducted in 2015/2016. The households access food through own production, income from sale of crop and livestock produce, monthly salaries and wages from casual jobs and incomes from small-scale businesses. A large proportion of the households in the county, estimated at 45.5 percent, access food mainly from own production (KIHBS, 2015). The main food crops grown in the county include maize, beans, cow peas, sorghum, green grams, and cassava. Agriculture is a key economic activity in the county but it is faced with various challenges which include, low productivity, low adoption of technologies, and poor input access among others (Makueni County Government, 2018). The county largely depends on natural weather patterns for food production and low usage of productive inputs with lack of water catchment facilities cause severe food shortages during periods with insufficient rainfall (Mutie, 2017).

The County Government has been undertaking development of community water management projects and water harvesting techniques like dams, irrigation schemes and boreholes to improve overall water supply to boost agricultural production through irrigation as well as horticultural production in the County. To support training of farmers on modern farming techniques, the county government has enhanced and furnished an agricultural training centre targeting the youths to increase the participation and contribution of the youths in agriculture and attainment of food sufficiency in the county. Most of the food is produced by small holder farmers who produce very little such that majority of the population still lack enough food (Makueni County 
Government, 2018). This study analysed the household food crop productivity among the small holder farmers to establish its main determinants so as to facilitate targeting of strategies to increasing small holder productivity.

\subsection{Objectives of the Study}

The main objective of this study was to analyse productivity of households in food crops production in Makueni County, Kenya.

The specific objectives were;

i. To determine the level of productivity of households in food crops production in Makueni County.

ii. To establish the determinants of productivity in food crops production in Makueni County.

\section{Empirical Literature}

Odhiambo et al. (2004) in a study to assess the sources and determinants of agricultural growth and productivity in Kenya for the period 1965 - 2001 used secondary data of land, capital and labour from the World Bank Africa Database. The study employed growth accounting approach to determine the sources of agricultural growth and value added in the agricultural sector was used to define productivity. Findings showed that agricultural productivity in Kenya is largely depended on the growth of land under cultivation, labour and capital, accounting for 90 percent of the total agricultural growth. Labour by itself, was found to account for the bulk of the growth in agricultural sector by 48 percent while capital and land accounted for 28 percent and 14 percent respectively. Land's contribution was found to be the least which was attributed to the low technological development in the sector.

Anyanwu (2013), in study to evaluate the determinants of agricultural productivity in Nigeria used cross sectional data of 80 smallholder farmers randomly selected from 2 agricultural zones in Nigeria. The study used multiple regression analysis to analyze the data. Aggregate productivity was measured by the index of the ratio of the total value of farm output to the value of total inputs used in farm production. A positive relationship with aggregate productivity was found on farm size, capital input, number of crops planted in a mixture in the farm, distance to the nearest market, level of education and farming experience. Labour input, expenditure on planting material, non-farm income, age of the farmer and household size were found to have a negative relationship with aggregate productivity.

Ong'ayo (2017) in a study to analyze how agricultural extension development initiatives affect household's agricultural food productivity used a sample of 150 small-scale farmers in Kilifi County of Kenya. Information on demographic data like age, education level and gender, landholding and utilization, crop diversification, agricultural technologies and initiatives was collected. Descriptive statistics was used in the analysis of the variables. The study findings indicated that the level of education, use of the appropriate agricultural technologies and all the development initiatives were significant in increasing household food productivity. In addition, land tenure systems were found to influence farmers' response and adoption of development initiatives that consequently affected the impact on crop productivity positively.

Muraya (2017), sought to establish the level of agricultural productivity in Kenya by analyzing the determinants of agricultural productivity using a time series data from the period 1980 to 2013 . Productivity was defined as value added per worker and it was hypothesized as a function of labour force, government expenditure, rainfall and the general price level. The study used Ordinary Least Squares (OLS) method of estimation to estimate the parameters of the model. The study findings indicated that government expenditure, rainfall and labour force were positively correlated to agricultural productivity while general price level was negatively correlated to productivity.

Onogwu, Audu and Igbodor (2017) in a study to determine factors influencing agricultural productivity interviewed 150 small-holder farmers randomly selected in Taraba State, Nigeria. For each farmer, productivity was measured as total value product in a year and as a function of age of the farmer, experience, credit, farm size, gender, education level, extension services and membership of farmers to farm-based organizations. The study findings indicated that, access to credit, the size of the farm, level of education and membership to a farm-based organization had a positive impact on productivity. On the other hand, access to extension services, age, experience and gender of the farmer, had no significant influence on productivity.

Ateka, Onono and Etyang (2018) in a study to analyze productivity and its determinants in a smallholder tea 
production in Kenya used survey data from a random sample of 525 farming households in Bomet and Nyamira Counties in Kenya. Productivity was measured as tea output per unit area. The independent variables included gender and age of the household head, farm size, age of the farm, access to extension services, distance to the nearest market, household size, level of education, labour, access to credit and market channels. The study used a semi log productivity regression model to investigate the determinants of productivity. The study findings indicated that farm size, the intensity of family labor applied, access to extension through the farmer field schools, credit utilization, tea marketing arrangements and location had significant influence on tea productivity. Distance to the market, household size, level of education, age of the farm, age and gender of the farmer has no significant influence on productivity.

Findings from the empirical studies indicated that partial productivity is the most commonly used to measure the level of productivity. Muraya (2017) and Odhiambo et al. (2004) showed productivity as value added per worker. Anyanwu (2013) measured aggregate productivity as an index of the ratio of the total value of farm output to the value of total inputs used in farm production. In addition, the existing studies have established a range of factors that influence agricultural productivity. For instance, size of the farm, labor input, expenditure on planting materials and fertilizers, non-farm income, capital input, education level and age of the farmer, size of household and farming experience are some of the determinants of agricultural productivity. The key factors to agricultural productivity have been well documented as well as the response measures and were found to fluctuate depending on the intensity of use of the farm inputs. Despite response measures being in place to increase productivity, food availability is still a major concern due to the existence of stagnant crop yields. The study sought to fill the knowledge gap by establishing the factors which influence productivity among small holder farmers in Makueni County to ensure efforts are focused in enhancing productivity and increasing farm incomes to lower food poverty rates and ensure food security in the long run.

\section{Theoretical Framework}

The general classical economics describe production as the process through which inputs are transformed into outputs (Koutsoyiannis, 2006). The relationship between inputs and the maximum outputs is generally expressed in a production function. For every farming household, the level of output depends on the given input or a set of inputs, such that:

$Y=f\left(X_{i}\right)$.....

Where $\mathrm{Y}$ can be output from use of one input $\left(\mathrm{X}_{\mathrm{i})}\right.$ or output from use of multiple inputs $\left(\mathrm{X}_{\mathrm{i}} \mathrm{s}\right)$.

Productivity of single input is referred to as partial factor productivity whereas from aggregate inputs is referred to as the total productivity (Sumanth, 1997), so that for every farming household, the ratio of total output to total input(s) gives the farm's productivity as follows:

$P_{a}=Y / X_{i}$

Where, $\mathrm{Y}$ is the total value of farm output and $\mathrm{X}_{\mathrm{i}}$, is the total value of inputs applied on the farm to produce the given value of output. For a single input, $\mathrm{P}_{\mathrm{a}}$ will be partial farm productivity whereas for a set of inputs, $\mathrm{P}_{\mathrm{a}}$ will be total farm productivity.

In small holder production, farmers grow different crops per unit area of land cultivated (Fladby, 1983). Therefore, their productivity is well captured by total value of all the crops grown per area of land cultivated as in equation 3 :

$P_{h}=\frac{\sum_{i=1}^{n} W i * P i}{A}$.

Where, $\mathrm{P}_{\mathrm{h}}$ is the total farm productivity for each household, total output $(\mathrm{Y})$ in equation 2 is given as $\sum \mathrm{W}_{\mathrm{i}} * \mathrm{P}_{\mathrm{i}}$ in equation 3, where $\mathrm{W}$ is the weight of the crop harvested in Kilograms, $\mathrm{P}$ is the price per kilogram and $\mathrm{A}$ is the area of land cultivated, $\mathrm{i}=1,2, \ldots, \mathrm{n}$ representing different crops grown on the farm.

Borrowing from the theory of production, at any particular time, given the technology available to a producer, there is always a level of output which is realized from a set of inputs employed. The traditional production function highlights three farm inputs: land, labour and capital (Dharmasiri, 2009). For a farm producer, productivity from a given land would depend on the quality of inputs of labour and capital used.

$\frac{Y}{A}=f(L, K)$

Where, A, L and $\mathrm{K}$ are land, labour and capital respectively and $\mathrm{Y}$ is the level of farm output and output per area of land $(Y / A)$ gives the productivity. Land productivity may be influenced by land characteristics such as 
ownership of land, soil fertility, soil nutrients, water availability, mixed cropping and type of seeds planted (Fladby, 1983). Labour characteristics associated with productivity include the source of labour, farming skills and knowledge, trainings, extension services and farming experience. Capital characteristics which may influence productivity include; - farming technologies applied such as use of improved machineries like a tractor, irrigation tools and use of improved seeds, fertilizers and manure (Shafi, 1984).

Based on productivity theory, equation 4 was extended so that agricultural productivity is influenced by both land and labour characteristics, availability of technology and use of machinery as well as demographic characteristics of the farmer such as level of education, sex of the household head, marital status as well as farm management practices and institutional support services.

$\frac{Y}{A}=f\left(L, K, D_{f}, F_{p}\right)$

Where $\left(Y_{A}\right)$ is the crop productivity (farm output per unit area of land cultivated), L represents labour characteristics, $\mathrm{K}$ represents capital and machinery applied, $\mathrm{D}_{\mathrm{f}}$ represents the farmers' demographic characteristics and $\mathrm{F}_{\mathrm{p}}$ represents the farm management practises and other support services.

\section{Materials and Methods}

4.1 Study area and Sampling

The study was conducted in Kaiti constituency of Makueni County using a survey research design. The study utilized primary data from 100 farming households. Convenience sampling technique was employed to select farming households to participate in the survey as it was a fast and an easy method to reach the farming household heads who were available and willing to participate in the survey through face to face interviews during the COVID-19 Pandemic. Interviews were conducted using structured schedules that captured all the required information from the households including crops grown, outputs from previous season, farming technologies used and farm household demographic characteristics.

\subsection{Empirical Model Specification}

Considering the fact that, small holder production, farmers grow different crops per unit area of land cultivated the empirical model used to determine productivity was specified as;

$$
C P i=\frac{\sum_{j=1}^{k} Q j i * P j}{A i}
$$

Where, $\mathrm{j}=1,2, \ldots, \mathrm{k}$ representing different crops grown and $\mathrm{i}=1,2, \ldots, \mathrm{n}$, representing different farmers.

$\mathrm{CP}_{\mathrm{i}}$ is the productivity for farmer $\mathrm{i}$

$\mathrm{Q}_{\mathrm{ji}}$ is quantity of crop output $\mathrm{j}$ for farmer $\mathrm{i}$

$P_{j}$ is the price per unit for crop $j$

$\mathrm{A}_{\mathrm{i}}$ is the total cropped area of land.

To analyze the determinants of household crop productivity, the empirical model was specified as;

$$
\text { CPi }=\text { f (SXi,AGi, LTSi, SDi, Fi, FEi, Li, ESi, FAi, Si, Di) }
$$

Where $\mathrm{i}=1,2,3 \ldots \mathrm{n}$ representing different farming households

$\mathrm{CP}$ is the crop productivity

SX is the sex of the household head

AG is age of the household head

LTS is the land tenure security

$\mathrm{SD}$ is type of seeds planted

F is use of fertilizers

$\mathrm{FE}$ is the farming experience

$\mathrm{L}$ is the source of labour employed

ES is access to extension services

FA is the type of farm equipment employed

$\mathrm{S}$ is Sale of Surplus Produce

$\mathrm{D}$ is the distance to the market 


\subsection{Description and Measurement of Variables}

Table 1: Description and measurements of the study variables

\begin{tabular}{|c|c|c|}
\hline Variable & Definition & Measurement \\
\hline Crop productivity $\left(\mathrm{CP}_{\mathrm{i}}\right)$ & Total crop yields. & $\begin{array}{l}\text { Measured by an index of the ratio of total } \\
\text { value of crops harvested per unit of land } \\
\text { cultivated. }\end{array}$ \\
\hline Total Crop Output $\left(\mathrm{Q}_{\mathrm{j}}\right)$ & Quantity of the crops harvested. & Measured in Kilograms (Kg) \\
\hline Output Price $\left(\mathrm{P}_{\mathrm{j}}\right)$ & $\begin{array}{l}\text { Amount of money expected or } \\
\text { given in payment for the output. }\end{array}$ & Measured in Kenyan Shillings (Kshs) \\
\hline Area of land $\left(\mathrm{A}_{\mathrm{i}}\right)$ & $\begin{array}{l}\text { The size of land cultivated for } \\
\text { growing of crops. }\end{array}$ & Measured in hectares (ha). \\
\hline $\begin{array}{l}\text { Sex of the household head } \\
\left(\mathrm{SX}_{\mathrm{i}}\right)\end{array}$ & $\begin{array}{l}\text { Either of the two gender } \\
\text { categories (Male or female) }\end{array}$ & $\begin{array}{l}\text { Measured by dummy variable, } 1 \text { if male } \\
\text { and } 0 \text { if female }\end{array}$ \\
\hline $\begin{array}{l}\text { Age of the household head } \\
\left(\mathrm{AG}_{\mathrm{i}}\right)\end{array}$ & $\begin{array}{l}\text { Period lived by the household } \\
\text { head. }\end{array}$ & Measured in years. \\
\hline $\begin{array}{lll}\text { Land } & \text { Tenure } & \text { security } \\
\left(\text { LTS }_{\mathrm{i}}\right) & & \end{array}$ & $\begin{array}{l}\text { State of exclusive rights and } \\
\text { control over the use of land. }\end{array}$ & $\begin{array}{l}\text { Measured by a dummy variable, } 1 \text { if } \\
\text { ownership is by the farming household, } 0 \text { if } \\
\text { otherwise. }\end{array}$ \\
\hline Type of Seeds $\left(\mathrm{SD}_{\mathrm{i}}\right)$ & $\begin{array}{l}\text { The kind of seeds used by the } \\
\text { farmers. }\end{array}$ & $\begin{array}{l}\text { Measured by a dummy variable, } 1 \text { if the } \\
\text { farmer used hybrid seeds, } 0 \text { if otherwise. }\end{array}$ \\
\hline Fertilizers $\left(\mathrm{F}_{\mathrm{i}}\right)$ & $\begin{array}{l}\text { Chemicals or natural substances } \\
\text { added to the land during crop } \\
\text { production. }\end{array}$ & $\begin{array}{l}\text { Measured by a dummy variable } 1 \text { if the } \\
\text { farmer used } \mathrm{f} \text { fertilizers/manure to grow } \\
\text { crops, } 0 \text { if otherwise. }\end{array}$ \\
\hline Farming experience $\left(\mathrm{FE}_{\mathrm{i}}\right)$ & $\begin{array}{l}\text { Knowledge and skills in farm } \\
\text { production exhibited over a } \\
\text { period of time. }\end{array}$ & $\begin{array}{l}\text { Measured in number of years in farming } \\
\text { activities. }\end{array}$ \\
\hline Labour Employed $\left(\mathrm{L}_{\mathrm{i}}\right)$ & $\begin{array}{l}\text { Source of labour employed in } \\
\text { the crop production. }\end{array}$ & $\begin{array}{l}\text { Measured by a categorical variable, L1; } 1 \\
\text { if hired labour, } 0 \text { if otherwise and L2; } 1 \text { if } \\
\text { both hired and family and } 0 \text { if otherwise }\end{array}$ \\
\hline Extension services $\left(\mathrm{ES}_{\mathrm{i}}\right)$ & $\begin{array}{l}\text { Technical advice and } \\
\text { information to farmers on new } \\
\text { ideas developed by agricultural } \\
\text { research institutions. }\end{array}$ & $\begin{array}{l}\text { Measured by a dummy variable, } 1 \text { if farmer } \\
\text { has access to extension services and } 0 \text { if } \\
\text { otherwise. }\end{array}$ \\
\hline Farm equipment $\left(\mathrm{FA}_{\mathrm{i}}\right)$ & $\begin{array}{l}\text { Type of equipments and plant } \\
\text { machinery such as oxen plough, } \\
\text { tractor and hand tools used in } \\
\text { the food crop production } \\
\text { process. }\end{array}$ & $\begin{array}{l}\text { Measured by a dummy } \\
\text { plough ariable, } 1 \text { if oxen } \\
\text { (tractor). }\end{array}$ \\
\hline $\begin{array}{l}\text { Sale of Surplus Produce } \\
\left(\mathrm{S}_{\mathrm{i}}\right)\end{array}$ & $\begin{array}{l}\text { Whether the farmer sold any } \\
\text { amount of the crop output. }\end{array}$ & $\begin{array}{l}\text { Measured by a dummy variable, } 1 \text { if farmer } \\
\text { sold surplus produce and } 0 \text { if no otherwise }\end{array}$ \\
\hline Distance to the Market $\left(\mathrm{D}_{\mathrm{i}}\right)$ & $\begin{array}{l}\text { Approximate distance between } \\
\text { the the farming household and } \\
\text { the market place. }\end{array}$ & Measured in Kilometres $(\mathrm{Km})$ \\
\hline
\end{tabular}

\subsection{Data Analysis and Diagnostic Tests}

Data collected was examined and checked for completeness and consistency of the information required in addressing all the study objectives. The data was then coded accordingly and recorded into an excel sheet for analysis. The study used descriptive and inferential statistical techniques in data analysis. The descriptive analysis included means and standard deviation for the continuous variables and frequency distribution of categorical variables in the study. Correlation analysis was also done to check the collinearity between the explanatory variables. To establish the level of household crop productivity the average productivity concept was applied whereas to establish the determinants of the household food crop productivity, linear regression model 
was employed. The Stata software was used to analyse the information. To validate that the model was free from specification errors the study conducted the Ramsey RESET test. The model was subjected to multicollinearity test using the variance inflation factor (VIF) and heteroscedasticity test using the White's test for heteroscedasticity to establish any significant relationship between the explanatory variables and the error term to avoid coefficient biasness.

\section{Results and Discussions}

5.1 Descriptive Statistics

Summary on the data on continuous variables in the study are presented in table 2

Table 2: Descriptive Summary of the Continuous Variables

\begin{tabular}{lcccccc}
\hline Variable & Observations & Min & Max & Mean & \multicolumn{1}{c}{ Std. Dev } \\
\hline Age of Household Head (Years) & 100 & 26 & 68 & 44.45 & 8.793219 \\
Household Crop Productivity & 100 & 7,616 & 51,336 & $21,939.52$ & $10,249.33$ \\
Farming Experience (Years) & 100 & 2 & 40 & 15.45 & 8.794368 \\
Distance to the nearest market & 100 & .5 & 7 & 2.5 & 1.540759 \\
\hline
\end{tabular}

As shown in table 2, the mean age of household head was 44 years indicating that majority of the farming household heads were middle aged. The productivity of the households in food crops production ranged from Kshs.7, 616 and Kshs.51,336 with the average of Kshs. 21, 939.52 for the one cropping season. This indicated that household crop productivity was sufficiently distributed and fit for the analysis of its determinants using regression analysis. The minimum and maximum farming experience of the farming household head was 2 years and 40 years respectively with a mean of 15 years. This shows that in the sample there were new food crop producers as well as those who had been in the production for long periods. The latter are expected to have accumulated sufficient knowledge in the management of the crops and possibly could ensure high productivity. The average distance to the nearest market was found to be 2.5 kilometres which indicated that majority of the farming households have a close proximity to a marketplace. The households can therefore easily deliver surplus food produce at low costs. In addition, they can easily access the markets for purchase of the farm inputs.

For all the continuous variables in the study, the standard deviation is greater than zero. This meant that the farming households were sufficiently different along these characteristics. Therefore, all the variables could be included in a regression model.

For the categorical variables the frequency distribution is presented in the table 3.

Table 3: Summary of the Categorical Variables

\begin{tabular}{|llc|}
\hline Variable & Categories & Percentage \\
\hline Sex of the H/hold Head & Male (1) & 75 \\
Land Tenure Security & Female (0) & 25 \\
& Own land (1) & 91 \\
Type of Seed Planted & Otherwise (0) & 9 \\
& Hybrid (1) & 78 \\
Use of fertilizers & Not Hybrid (0) & 22 \\
& Household used fertilizer (1) & 64 \\
Source of Labour & Household did not use fertilizer (0) & 36 \\
& & \\
Access to Extension Services & Family (L1) & 14 \\
& Hired (L2) & 68 \\
Farming tools applied & Both Family \& Hired (0) & 18 \\
& No access (0) & 18 \\
Sale of surplus produce & Oxen plough \& Hand tools (1) & 82 \\
& Tractor (0) & 76 \\
& Farmer sold surplus (1) & 24 \\
\hline
\end{tabular}


As shown in table 3, 75 percent of the farming household heads were male, and 25 percent were female A large proportion of the farming households, (91 percent) cultivated their own land and therefore were expected to have positive incentives to invest, conserve, protect and reap the benefits of labour and capital invested. A good proportion of the farming households ( 78 percent) used hybrid seeds. Since hybrid seeds grow fast, adapt easily, are disease resistant, it was expected to lead to higher yields. 64 percent of the farming households used fertilizers. Fertilizers improve the quality of land, soil texture and increase crop yields which is geared towards increasing productivity levels (Morris et al., 2007).

The source of labour for majority of the farming households (68 percent) was hired labour. For the other households, 14 percent used family labour while 18 percent used both family and hired labour. Majority of the farming households had no access to extension services at 82 percent indicating poor dissemination of information on farm technologies, low support to farmers on farm technical and managerial skills. Access to extension services can help in increasing farm productivity and revenues towards poverty reduction, and food security (Shafi, 1984).

A large proportion of the farming households (76 percent) used oxen plough and hand tools during the reference cropping season compared to 24 percent who used tractors in cultivating land. The use of oxen plough and hand tools was common among many small holder farmers because they are readily available and easy to use. Most of the households ( 83 percent) sold surplus produce compared to 17 percent who had no surplus to sell. Households sold their surplus produce to other farmers, schools and institutions, traders and farm cooperatives in the area. Most of the farmers seem to produce the food crops for household consumption.

5.2 Productivity of households in food crops production

One of the objectives of the study was to determine the level of productivity among the smallholder food crop producers. In small holder production, farmers usually grow different crops on the same land. The study therefore collected data on output of all crops grown (in kilograms) for each household as well as market prices for the crops per unit (kilogram). This helped in determining the total value of farm produce for each household for the reference season. The summary on production of various food crops grown and the prices per unit during the season are given in table 4.

Table 4: Summary of Food crops and Price per Kilogram

Crop Number of Households $\quad$ Price per unit (Kg) in Kshs.

\begin{tabular}{lcc}
\hline Maize & 100 & 31 \\
Beans & 98 & 78 \\
Cowpeas & 45 & 33 \\
Green grams & 27 & 89 \\
Green peas & 8 & 102 \\
Pigeon peas & 51 & 33 \\
Sorghum & 12 & 28 \\
\hline
\end{tabular}

Table 4 shows that maize was grown by all households in the sample. This is because it is the staple crop for most Kenyans (Onono et al., 2013) and is also the main food crop grown in Makueni County (KNBS, 2019). Further, maize is one of the most adaptable crops under varied weather conditions. The other crops common among the households included beans, pigeon peas, cow peas and green grams. Although green peas attracted the highest price per kilogram, it was the least grown crop. This can be attributed to unfavourable climate for the crop as it requires cool-weather (Marwa et al, 2020) which is rare in Makueni County. To obtain the crop productivity for each household, the total value of farm produce was divided by the size of land cultivated in acres. Summation of all the households' productivity divided by the number of households gave the mean productivity. The mean level of productivity for the households was found to be Kshs. 21, 940 which gives the average return to each household on land cultivated for a given cropping season. 47 percent of the households had their crop productivity above the average while 53 percent were below average for the referenced cropping season.

Makueni County has two cropping seasons in a year. Assuming that produce from one season is to cover for six months, the reported results translated to a farm income level of Kshs. 3,657.00 per month per unit of land cultivated for a household. Given that the average household size was 6 people, this translated to a farm income of Kshs. 610.00 per person per month. In 2015, the Kenya National Bureau Statistics (KNBS) reported overall 
rural poverty line at Kshs.3, 252 per month per person, a value that includes minimum provisions for both food and non- food expenditures (KNBS, 2015). For households that rely solely on food crops farming the average household income per person is therefore below what is required to spend to lift a household out of poverty. The finding indicated that the level of household crop productivity is low and more efforts to increase productivity should be employed to increase the level of farm incomes and alleviate poverty among the households.

\subsection{Determinants of Household Food Crop Productivity in Kaiti Constituency}

The study performed regression analysis to establish the determinants of household food crop productivity. Household crop productivity was regressed on several variables including sex of the household head; age of the household head; land tenure security, type of seeds planted, use of fertilizers, years of farming experience, source of labour, access to extension services, farming tools applied, sale of surplus produce and distance to the nearest market. The results are reported in table 5 .

Table 5: Regression results on determinants of Household Crop Productivity

\begin{tabular}{|c|c|c|}
\hline \multicolumn{3}{|c|}{ Dependent Variable: Crop productivity } \\
\hline Variable & Coefficient & Std. Err. \\
\hline Sex of the household head & -222.1709 & 1991.535 \\
\hline Age of the household head in years & $-3121.752 *$ & 1825.373 \\
\hline Age squared & $39.76449 *$ & 20.54812 \\
\hline Land tenure security & $6633.318 * *$ & 3300.468 \\
\hline Type of seeds planted & -3482.825 & 238.508 \\
\hline Use of fertilizer & 2632.468 & 1880.005 \\
\hline Farming experience in years & 859.3854 & 770.9282 \\
\hline Farming experience in years ${ }^{2}$ & $-39.54874 *$ & 20.91423 \\
\hline Labour1 & -1430.528 & 3176.69 \\
\hline Labour2 & -1698.697 & 3720.408 \\
\hline Access to extension services & $6850.175 * * *$ & 2494.38 \\
\hline Farming tools applied & $-11179.98 * * *$ & 2226.677 \\
\hline Sale of surplus produce & 1651.893 & 2881.123 \\
\hline Distance to nearest market & $-2370.107 * * *$ & 602.3603 \\
\hline Constant & 86540.3 & 37118.07 \\
\hline $\mathrm{F}(14,85)=4.97$ & $000 \quad$ Adj R-squa & $=0.3595$ \\
\hline
\end{tabular}

To check for correlated explanatory variables, Variance Inflation Factor (VIF) on all the study variables was computed. Age and farming experience of the household head and land tenure security had a VIF of above 10. VIF above 10 indicates multicollinearity (Kennedy, 2003). The presence of multicollinearity does not mean that the model is mis specified as the regression coefficients remain unbiased and the standard errors remain valid (Dougherty, 2001). The study, therefore, included all the variables in the estimation of the regression model as the coefficients of age of the household, farming experience and land tenure security were found to remain unbiased indicating independent significant effect for each of the variables in the model. The model was also found to be free from specification errors through the Ramsey RESET test and the White's test which indicated that there was no heteroskedasticity.

As shown in table 5 , the probability of F-Statistic $(p=0.0000)$ is less than 0.05 level of significance which indicated that the model is statistically significant. The Adjusted R-squared was 0.3595 , implying that the independent variables in the model explained up to 35.95 percent of the variations observed in household food crops productivity among the farming households. From the regression results, coefficients of age of household head, age squared and farming experience in years squared were found to be significant at 10 percent level. The coefficient of land tenure security was found to be significant at 5 percent whereas for access to extension services, farming tools applied and distance to the nearest market the coefficients were found significant at 1 percent level. The rest of the independent variables had coefficients that were statistically insignificant. The insignificant coefficients suggest that sex of the household head, type of seeds planted, farming experience in years, use of fertilizers, source of labour and sale of surplus produce had no significant influence on the level of household crop productivity in Makueni County. 
The results show that, holding all other factors constant, as the age of the household increases by a year, there is a reduction in household productivity by Kshs.3,122 The reduction in productivity with age could be attributed to use of traditional methods and unlikelihood of old farmers to adopt new farming technologies which enhance productivity. As farmers grow old, most of them tend to employ and stick to the traditional methods of production without embracing modern technologies hence the reduction in productivity levels (Anyanwu, 2013). The coefficient of age-squared of household head indicated that the decrease in productivity is at an increasing rate. This suggests that the farmers become increasingly less productive as they get older.

The coefficient of land tenure security was positive and significant at 5 percent level of significance. This implied that farmers who produced food crops by cultivation of own land reported an average productivity of Kshs.6, 633 more than those who cultivated rented land. In the sample 91 percent of the farming household cultivated their own land as compared to only 9 percent who cultivated rented land. Cultivation of own land ensures continuous land improvements and enables a farmer to fully conserve, protect and reap the benefits of labor and capital invested which in turn results to high productivity (FAO, 2016). The finding was similar to that of Ong'ayo (2017) who found out that land security influences farmers' adoption of development initiatives that impact positively on crop productivity.

The coefficient of farming experience was positive implying that, as the farming experience of the household head increases by a year, there is an increase in household productivity by Kshs.859.38. However, the coefficient was not significant. On the other hand, the coefficient of farming experience in years squared was negative and significant at 10 percent level of significance. The results implied that, productivity increases with years of experience in farming, but the increase is at decreasing rate, a phenomenon that is consistent with diminishing returns. This may be attributed to long time farmers having exhausted all the possible strategies for increasing productivity.

The coefficient of access to extension services was positive and significant at 1 percent level of significance. The results indicated that, for a farming household with access to extension services, the household food crops productivity was Kshs. 6,850 more than for households that had no access to extension services. Only 18 percent of the farming households were found to have had access to extension services during the referenced cropping period while 82 percent did not have access. Extension services offers technical advice on agricultural production to farmers and also supply them with farm inputs and services to support and improve the productivity. In addition, it introduces new ideas from agricultural research stations and gives farmers information necessary in improving productivity. The findings were similar to those of Ateka, et.al (2018) in which access to extension services had a significant influence on small holder tea productivity in Kenya.

The coefficient of farming tools applied was negative and significant at 1 percent level of significance, suggesting that, households who used oxen plough realized lower productivity at an average of Kshs. 11,180 compared to households that used a tractor. In the sample, 76 percent of the farming households were found to have used oxen plough and hand tools during the cropping season compared to only 24 percent who used a tractor. This indicates that majority of the households employed a low mechanical technology. Low mechanical technologies are not fully efficient in production as they involve manual operations which are slow and takes a longer time in operations which may impact negatively on productivity. The finding is in line with the theoretical literature in that use of highly mechanized technologies results to more productivity as compared to low mechanized ones. Shafi (1984) stated that farming technologies applied such as use of improved machineries like tractor influences productivity positively.

The coefficient of distance to the nearest market was negative and significant at 1 percent level of significance. This implied that, an increase in distance to the nearest market by one kilometer results to a reduction in household crop productivity by Kshs.2, 370. Distance to nearest market determines the cost and time spent in accessing farm inputs, food items in case of depletion and also selling the farm surplus produce. The shorter the distance, the less the cost spend in acquiring the items and vice versa. The results are in line with those of Anyanwu (2013), ) who found a positive relationship on productivity and distance to the nearest market.

The coefficient of sex of the household head was negative and insignificant. This implied that sex of the household head was not important in the determination of the level of household food crop productivity. The results were similar to those of Onogwu, Audu and Igbodor (2017) who found out that gender of the farmer had no significant influence on productivity. The type of seeds planted was found to have no significant influence on household food crop productivity, whereas Shafi (1984) noted that, use of improved seeds had a significant influence on productivity. The coefficient of use of fertilizers was positive and insignificant, implying that use of 
fertilizers had no significant influence on household crop productivity. The findings differ with prepositions in theoretical literature that, the level of productivity can be raised by use of fertilizers (Fladby, 1983). The coefficient of labour 1 (L1) and labour 2 (L2) was negative and insignificant which indicated that the source of labour had no important influence on household crop productivity. The findings differ from those of Odhiambo et al. (2004) who found that labour accounts for the bulk of the growth in agricultural sector.

\section{Conclusions and Policy Implications}

The study concluded that the level of household food crops productivity in Makueni County is low and therefore not sufficient to lift households out of poverty. This is because the average household food crops productivity per person of Kshs.610 is below the required spending to lift one out of poverty. The study established that age of the household head, land tenure security, farming experience, access to extension services, farming tools employed and distance to the nearest market are the main determinants of household food crop productivity in Kaiti Constituency, Makueni County. This is because their coefficients in the regression model were statistically significant. Household food crops productivity is high among younger farmers and where a farmer cultivates own land and has access to extension services. Productivity was found to lower with use of hand tools and oxen plough than in cases where a farmer uses a tractor. Farmers that are nearer to the markets were found to have high productivity. From these findings, the study concluded that security of tenure, access to extension services, high level of mechanization and proximity to marketplaces impact positively on food crops productivity.

The low food crops productivity among households reported in the study can be imputed to the challenges faced by farmers in crop production. To address these challenges, there is a need for actions that can address the challenges along the established determinants of productivity. The County government of Makueni through the executive committee in agriculture, should ensure that extension services are easily accessible by the farmers. This may include; assisting farmers to make better use of resources, introducing new farming technologies, supplying of fertilizers and seeds which are aimed towards increasing productivity.

To promote market access for the farming households, the County government through the budgetary allocations by the National government should invest in rural industrialization by establishing rural markets within villages at a close proximity to farming households to reduce the distance to the markets. This will promote efficiency in farm production through expansion of the production inputs needed to increase agricultural output and multiplication of the number of plants available for processing farm commodities which in turn will increase the productivity levels. This is because the study findings revealed that farmers nearer to marketplaces had high productivity compared to those far away from the market.

To promote sustainable agricultural mechanization, the National County government through the Ministry of Agriculture should ensure that farming tools are economically affordable, environmentally sound and adaptable to local conditions flexible to changing climatic patterns. This can be addressed by protecting the farmers against price fluctuations. The County Government should in turn provide training to farmers on the appropriate tools, equipment and machinery to use on environmentally-sound agricultural practices. This is because the type of farming equipment employed was found to have a significant influence on household food crop productivity. The findings indicated that use of low mechanized tools such as hand tools and oxen plough reduced household food crops productivity, hence there is need to use highly mechanized tools to enhance productivity.

To promote land tenure security, the National Government should ease the processes and the procedures of land registration in formalizing land rights. This will ensure farmers have security of tenure over the land they own and cultivate. Cultivating own land ensures continuous land improvements and enables the farmer to fully conserve, protect and reap the benefits of labour and capital invested which in turn results to high household productivity.

\section{References}

Ahishakiye, J. (2011). Influence of agricultural production techniques on food security in Burundi: A case study of Ngozi (Doctoral dissertation, Master's dissertation, Ghent University).

Anyanwu, S. (2013). Determinants of Aggregate Agricultural productivity among high external inputs technology farms in a harsh macroeconomic environment of IMO state, Nigeria. African Journal of Food, Agriculture, Nutrition and Development, 13(5), 8238-8248.

Ateka J.M, Onono P.A, M. Etyang. (2018). Productivity and its Determinants in smallholder Tea Production in 
Kenya: Evidence from Bomet and Nyamira Counties of Kenya."Journal of Agricultural Economics and Rural Development. Vol 4(2). pp. 416-422.

Blanchard, O. J. (1967). Comment, Journal of Business and Economic Statistics, vol. 5, 1967, 449-451.

Dharmasiri, L. M. (2009). Applicability of Cobb-Douglas Function in Measuring Spatial Variation of Agricultural Productivity in Sri Lanka - 2009. Paper presented at the National Geography Conference, Peradeniya: University of Peradeniya.

Dougherty, C (2001). Introduction to econometrics, 5th edition, London School of Economics and Political Science, United Kingdom: Oxford University Press.

Fladby, B. (1983). Household Viability and Economic Differentiation in Gama, Sri Lanka. Bergon Occasional Paper in Social Anthropology, No. 28. Bergon: University of Bergon.

Food and Agriculture Organization, (2006). World base reference for soil resources. Report on World Soil Resources. Rome, FAO. Italy.

Food and Agriculture Organization, (2014). The State of Food Insecurity in the World: Strengthening the enabling environment for food security and nutrition. Rome, Food and Agriculture Organization of the United Nations.

Food and Agriculture Organization, (2015). World Food Programme on the State of Food Insecurity, Rome, Food and Agriculture Organization of the United Nations.

Gregory, P. J., Ingram, J. S., \& Brklacich, M. (2005). Climate change and food security. Philosophical Transactions of the Royal Society B: Biological Sciences, 360(1463), 2139-2148.

International Food Policy Research Institute (2018). Global food policy report 2018.

Kenya National Bureau of Statistics, (2015). Ministry of Devolution and National Planning: Kenya Integrated Household Budget Survey Report. Nairobi, KNBS.

Kenya National Bureau of Statistics, KNBS. (2019). 2019 Kenya Population and Housing Census. Nairobi, KNBS.

Koutsoyiannis, D. (2006). A toy model of climatic variability with scaling behavior. Journal of Hydrology, 322(1-4), 25-48.

Makueni County Government, (2018). County Integrated Development Plan.

Marwa, M. A., El-Shafie, A. F., Dewedar, O. M., Molina-Martinez, J. M., \& Ragab, R. (2020). Predicting the water requirement, soil moisture distribution, yield, water productivity of peas and impact of climate change using SALTMED model. Plant Archives, 20(1), 3673-3689.

Muraya, B. W. (2017). Determinants of agricultural productivity in Kenya. International Journal of Economics, Commerce and Management, 5(4), 159-179.

Mutie, S. S. (2017). Household characteristics, farm use practices and effect on household food security in Kathonzweni Sub-County, Makueni County. University of Nairobi Doctoral dissertation.

Odhiambo, W., Nyangito, H. O., \& Nzuma, J. (2004). Sources and Determinants of Agricultural growth and productivity in Kenya. Nairobi, Kenya: Kenya Institute for Public Policy Research and Analysis (KIPPRA), Discussion paper No. 34.

Ong'ayo, A. H. (2017). Analysis of the effect of agricultural extension development initiatives on household"e $\mathrm{s}$ agricultural food productivity and sufficiency among small-scale farmers: A case of Kilifi County, Kenya. Journal of Agriculture and Food Science, 5(2), 13-20. 
Onogwu, G. O., Audu, I. A., \& Igbodor, F. O. (2017). Factors influencing agricultural productivity of smallholder farmers in Taraba State, Nigeria. International Journal of Agriculture Innovations and Research, $6(1), 114-118$

Onono, P. A., Wawire, N. W., \& Ombuki, C. (2013). The response of maize production in Kenya to economic incentives. International Journal of development and Sustainability, 2(2), 530-543.

Palitza, K. (2013). News analysis: Africa’s rapid urbanisation sets a time bomb. Retrieved June 19, 2013.

Republic of Kenya (2004), Strategy for Revitalising Agriculture, Government Printer, Nairobi.

Republic of Kenya (2010), Agricultural Sector Development Strategy, Government Printer, Nairobi.

Shafi, M. (1984). Agricultural Productivity and Regional Imbalances. New Delhi: Concept publishing company.

Slovin, E. (1960). Slovin's formula for sampling technique. [Paper reference 1].

Sumanth, D. J. (1997). Total productivity management (TPmgt): a systemic and quantitative approach to compete in quality, price and time. CRC Press.

United States Agency for International Development, (1995). Food Security Policy Paper. USAID, March 1995.

World Bank. (2017). World Bank data. United States World Bank. 